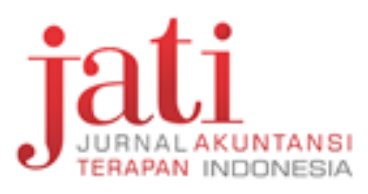

Jurnal Akuntansi Terapan Indonesia Vol 3 No 2 Hal 70-79 October 2020

Affiliation:

Universitas PGRI Madiun

*Correspondence:

ellyastuti@unipma.ac.id

This Article is Avalilable in: https://journal.umy.ac.id/index. php/jati/article/view/9557

DOI:

https://doi.org/10.18196/jati.030228

Citation:

Sholikah, M., Isharijadi, I., \& Astuti, E. (2020). Analisis Penerapan Akuntansi Syariah Pada Skema Jual Beli KPR Syariah. Jati: Jurnal Akuntansi Terapan Indonesia, 3(2), 70-79.

\section{Article History}

Received:

18 Agustus 2020

Reviewed:

05 September 2020

Revised:

26 October 2020

Accepted:

02 November 2020

Topic Article:

Akuntansi Syariah

\title{
Analisis Penerapan Akuntansi Syariah Pada Skema Jual Beli KPR Syariah
}

\author{
Mar'atus Sholikah'1 ${ }^{1}$ Isharijadi ${ }^{2}$, Elly Astuti*3
}

\begin{abstract}
:
This study aimed to analyze the application of Islamic accounting in the Islamic credit transaction scheme in housing sales at PT MIB and to find out the Islamic law review related to the difference in cash prices and credit prices that have been included in the sales brochure whether it contains usury. The research was a qualitative study with a descriptive approach. Also, the data were primary and secondary data sources, and the data collection techniques were through observation, interviews, and documentation. In addition, the study uses the triangulation of sources. Data analysis techniques are data collection, data reduction, data presentation, and data verification. The results of PT MIB's research use alternative economic and inflation methods. Based on PSAK 102 Accounting for murabahah and ISAK 101 regarding the recognition of murabahah income without any significant risks related to inventory ownership, and the use of both methods is permitted. Based on this method, it is time that has economic value so that when there is a deferral of payments, a certain amount of compensation is needed because basically money is the medium of exchange for the public. The faster the rotation, the better. Credit buying and selling mechanism are also allowed in the Qur'an, Hadith, and Ijma.
\end{abstract}

Keywords: Islamic Accounting, Credit Sale and Purchase, Systematic Calculation.

\begin{abstract}
Abstrak:
Penelitian ini bertujuan untuk menganalisis penerapan akuntansi syariah pada skema jual beli kredit syariah dalam penjualan perumahan di PT MIB dan mengetahui tinjauan hukum islam terkait dengan perbedaan harga tunai dan harga kredit yang telah dicantumkan dalam brosur penjualan apakah ada unsur riba atau tidak. Jenis penelitian ini menggunakan studi kualitatif dengan pendekatan deskriptif. Adapun sumber data yang digunakan berupa sumber data primer dan sumber data sekunder. Teknik pengumpulan data menggunakan observasi, wawancara dan dokumentasi. Penelitian ini menggunakan triangulasi sumber. Teknik analisis data adalah pengumpulan data, reduksi data, penyajian data dan verifkasi data. Hasil penelitian PT MIB menggunakan metode inflasi dan ekonomi alternatif. Berdasarkan PSAK 102 Akuntansi murabahah dan ISAK 101 mengenai pengakuan pendapatan murabahah tangguh tanpa resiko signifikan terkait kepemilikan persediaan, penggunaan kedua metode tersebut diperkenankan. Berdasakan metode tersebut, waktu lah yang memiliki nilai ekonomi sehingga ketika terjadi penagguhan pembayaran, diperlukan sejumlah kompensasi karena pada dasarnya uang adalah alat tukar milik publik. Semakin cepat perputarannya akan semakin baik. Hal ini juga sesuai dengan ketentuan Al-Qur'an, Hadis dan Ijma yang menyatakan bahwa jual beli kredit diperbolehkan.
\end{abstract}

Kata Kunci: Akuntansi Syariah, Jual Beli Kredit, Sistematika Perhitungan. 


\section{PENDAHULUAN}

Syariah bukan hanya mencakup hubungan manusia dengan Tuhan saja seperti sholat, puasa, zakat dan haji akan tetapi syariah lebih menekankan pada hubungan manusia dengan manusia lainnya, hubungan manusia dengan alam semesta dan hubungan menusia dengan kehidupan dimana ia berusaha mencari karunia Allah SWT dengan cara halal (Rahmanti, 2012). Akuntansi syariah merupakan teknik akuntansi yang berperan penting untuk memastikan operasional perusahaan berjalan sesuai syariat (Wardi \& Putri, 2011), harus berdasarkan pada nilai etika syariah yang bersumber dari Al-Qur'an, hadits dan ijma' Ulama (Maulidi AC, 2014) serta memiliki konsep keadilan, kebenaran dan pertanggungjawaban (Apriyanti, 2017). Akuntansi syariah mengatur prinsip muamalah seperti kegiatan jual beli dimana jual beli merupakan bagian dari tolong menolong antar umat manusia dimana hal ini sudah tercantum didalam Al-Qur'an dan Hadits. Dalam islam pelaksanaan kegiatan jual beli harus dilaksanakan dengan cara yang sah dan tidak dijadikan sebagai ajang bisnis yang kurang sehat, dalam arti tidak ada pihak yang merasa dirugikan atas transaksi yang dilaksanakan.

Skema jual beli yang berlaku secara umum adalah jual beli secara tunai dan jual beli secara kredit (Al-Banjari, 2016). Jual beli kredit dalam artian fikih muamalah disebut al-bai' bittaqsith yaitu transaksi jual beli yang dilakukan dengan mencicil atau mengangsur pembayaran dalam kurun waktu tertentu dengan jumlah nominal yang telah disepakti antar kedua belah pihak(Al-Banjari, 2016). Terdapat beberapa manfaat dalam jual beli kredit diantaranya bisa membuat dagangan cepat laku selain itu, para pembeli bisa mendapatkan barang yang diinginkannya walaupun mereka belum memiliki cukup uang (Khaer \& Nurhayati, 2019). Ulama fiqih berbeda pendapat mengenai transaksi jual beli kredit. Hal-hal yang diperselisihkan dalam transaksi jual beli kredit antara lain persoalan hukum yang mengerucut akan munculnya riba (Nasution, 2016). Ulama-ulama fiqih menerangkan salah satu sebab munculnya riba dalam jual beli yaitu adanya sistem pembayaran tunda atau mengangsur. Dengan adanya penundaan pembayaran maka identik dengan harga yang dinaikkan. Harga barang yang dijual menjadi mahal apabila dijual dengan sistem kredit atau pembayaran tunda.

Fenomena jual beli kredit yang sering ditemui pada masyarakat salah satunya adalah KPR. Produk KPR mulai tumbuh dan berkembang pada lembaga perbankan syariah dengan berbagai macam kelebihan yang ditawarkan (Qarizah \& Prabowo, 2013). Selain itu, saat ini mulai berkembang pula produk KPR yang berasal dari Lembaga non perbankan. Menurut Firmansyah \& Indika (2017) KPR syariah tanpa bank banyak diminati oleh masyarakat yang hendak membeli rumah. Hasil penelitiannya menunjukkan bahwa mayoritas respoden yang memilih KPR syariah tanpa bank ialah mereka para keluarga muda yang berpenghasilan rata rata menengah ke atas yang mempunyai latar belakang pendidikan yang baik. KPR sangat membantu masyarakat dalam mewujudkan keinginannya untuk mendapatkan aset yang sesuai dengan pendapatannya.

PT MIB merupakan pihak pengembang atau developer yang bergerak dibidang penjualan properti dengan sistem syariah. KPR syariah merupakan pembiayaan kepemilikan rumah yang ada di perusahaan dalam kegiatan pengolahan lahan dan pengadaan bangunan berdasarkan prinsip syariah tanpa melibatkan pihak bank (Irawan, 2019). Segmen operasional seperti itulah yang dilaksanakan oleh PT. MIB. Perusahaan menawarkan rumah dengan tipe yang berbeda-beda. Misalnya tipe Al-Ma'wa dengan luas tanah $90 \mathrm{~m}^{2}$ dan luas bangunan $105 \mathrm{~m}^{2}$ harganya Rp.550.000.000,- apabila membayar cash tetapi dengan sistem kredit harganya naik menjadi Rp.655.000.000,- dengan membayar uang muka sejumlah 200.000.000,- untuk waktu 3 tahun dan angsuran perbulannya sejumlah Rp.12.367.000,-. Sedangkan untuk 5 tahun harga rumah naik menjadi Rp.725.000.000 dengan angsuran perbulan yaitu Rp.8.750.000. Harga rumah untuk waktu 10 tahun berubah menjadi 
Rp.900.000.000 dengan angsuran perbulan Rp.5.835.000. Berdasarkan hasil observasi dan wawancara awal disampaikan bahwa kenaikan harga tersebut merupakan kompensasi atas penundaan pembayaran pelanggan.

Berdasarkan uraian diatas, penelitian ini berusaha mengungkapkan bagaimanakah praktik akuntansi syariah pada sistem jual beli KPR Syariah. Peneliti tertarik dengan proses perhitungan perbedaan harga tunai dan harga kredit dari tahun ke tahun yang telah dicantumkan dalam skema brosur penjualan PT MIB. Dari skema yang telah dicantumkan, dengan adanya perbedaan harga tunai dan harga kredit, maka dilakukan peninjauan hukum islam mengenai permasalahan tersebut apakah terdapat unsur riba ataukah tidak. Penelitian ini memberikan kontribusi pada pengembangan teori akuntansi Syariah khususnya pada praktik penerapan prinsip Syariah dalam transaksi jual beli kredit KPR.

\section{METODE PENELITIAN}

Penelitian ini menggunakan studi kualitatif dengan pendekatan deskriptif. Teknik pengumpulan data menggunakan observasi. Observasi dilakukan dengan teknik observasi terus terang atau tersamar, sehingga dengan kedua teknik tersebut peneliti berpeluang untuk mendapatkan hasil observasi yang fokus dan terarah, sehingga informasi lebih efektif dan jelas sesuai hasil yang diharapkan. Beberapa hal yang diobservasi adalah prosedur dan kebijakan penerapan akuntansi syariah pada skema jual beli kredit syariah PT MIB.

Sebelum melaksanakan wawancara, peneliti membuat pedoman wawancara untuk menggali informasi lebih lanjut. Adapun informan dipilih dengan menggunakan metode purposive yaitu Manajer PT MIB, Bagian Marketing (pemasaran), dan Bagian Kantor. Di samping itu, wawancara juga dilakukan kepada pembeli sebagai proses trianggulasi guna mendukung kevalidan data. Peneliti mendokumentasikan hasil wawancara berupa rekaman audio dan foto ketika proses wawancara berlangsung. Selain itu peneliti juga mendokumentasikan perjanjian akad jual beli antara PT MIB konsumennya, syarat yang harus dipenuhi pembeli yang akan membeli rumah, skema perhitungan perbedaan harga tunai dan harga kredit, struktur organisasi PT MIB. Tahap pengolahan data yang digunakan adalah pengumpulan data, reduksi data, penyajian data dan verifkasi data.

\section{HASIL DAN PEMBAHASAN}

Konsep properti syariah adalah kegiatan properti dimana pihak PT MIB selaku pengembang atau developer membeli lahan. Kemudian lahan tersebut dibangun oleh PT MIB dan dijual kepada pembeli dengan sistem syariah yaitu transaksi didasarkan pada aturan agama islam dan harus saling ridho antar kedua belah pihak yaitu penjual dan pembeli. Hal ini didukung pernyataan pimpinan PT MIB adalah sebagai berikut:

"Apabila rumah tersebut sudah jadi kami jual kepada pembeli atau konsumen dengan konsep syariah yaitu tidak menggunakan skema ribawi dan didasarkan saling ridho antar kedua belah pihak."

PT MIB menggunakan prinsip 7p dalam transaksi penjualan rumah 7p tersebut antara lain Tanpa bank, tanpa riba, tanpa bunga, tanpa denda, tanpa sita, tanpa asuransi, dan tanpa akad bermasalah. Tanpa bank maksudnya, tidak adanya pihak ketiga dalam pelaksanaan transaksi jual beli. Transaksi hanya dilakukan 2 pihak saja yaitu PT MIB sebagai penjual dan pihak ke-2 yang merupakan pembeli rumah. Tanpa denda maksudnya, apabila pembeli mengalami resiko keterlambatan dalam membayar angsuran maka, tidak ada denda melainkan pembayaran dapat dilakukan pada bulan berikutnya. Tanpa bunga yaitu dalam transaksi jual beli kredit di PT MIBtidak ada bunga yang dibebankan dalam pembayaran 
angsuran setiap bulannya. Harganya jelas berdasarkan kesepakatan awal dimana harga rumah sesuai dengan skema perhitungan yang sudah tercantum di brosur penjualan. Tanpa riba dalam tarnsaksi jual beli kredit transaksi harus didasarkan pada ketentuan dalam agama islam. Tanpa sita adalah apabila sewaktu waktu pembeli mengalami resiko gagal bayar pihak PT MIB tidak akan menyita rumah akan tetapi pembeli diberikan alternatif untuk melakukan pembaruan akad memberikan jaminan kepada pembeli untuk bisa membayar lagi, dan pembeli bisa minta tolong kepada pihak PT MIB untuk menjualkan rumahnya, kemudian pihak PT MIB hanya meminta kekurangan pembayarannya saja. Tanpa asuransi menurut pihak PT MIB asuransi merupakan sebuah janji dimana janji itu tidak bisa diandalkan karena sifatnya bisa diingkari atau dilaksanakan sehingga tidak cocok untuk objek transaksi. Tanpa akad bermasalah maksudnya, pihak PT MIB hanya melakukan satu akad saja yaitu bit-ain wattaqsith atau akad jual beli kredit tidak ada akad lain seperti sewa menyewa, hutang piutang, dan sebagainya.

Merujuk pada ketentuan dalam Al- Qur;an, Hadist dan ljma ulama, praktik jual beli kredit yang dilakukan pada PT MIB sah secara syariah. Adapun dasar hukum yang digunakan sebagai rujukan adalah sebagai berikut:

Surat Al-Baqarah ayat 275:

"Allah telah menghalalkan jual beli dan mengharamkan riba"

$$
\text { وَأَحَلَّ اللَّهُ الْبَيْعَ وَحَرَّمَ الرِّبَا }
$$

Hadis riwayat Aisyah ra.:

$$
\text { عن عائشة رضي الله عنها، قالت: (انشترى رسول الله صلى الله عليه وسلم من يهودي طعاما بنسيئة،ور هنه }
$$

"Dari 'Aisyah r.a, bahwa Nabi Saw pernah membeli makanan dari orang yahudi dengan pembayaran tidak tunai (dengan kententuan waktu tertentu) dan beliau gadaikan baju besinya padanya." (HR. Bukhori-Muslim).

Ulama yang memperbolehkan jual beli dengan sistem kredit juga berhujjah dengan kaidah:

"Pada dasarnya hukum mu'amalah adalah halal, kecuali ada dalil yang melarangnya"

Terkait dengan Persyaratan dan Alur Pembelian Properti Syariah di PT MIB, Keseluruhan informan menyatakan bahwa persyaratan administrasi dalam pembelian kredit rumah berupa KK, KTP, SIUP, NPWP, SK, SITU, Akta Nikahdan dokumen lainnya. Alur pembelian properti syariah di PT MIB dilakukan beberapa cara 1) PT MIB melakukan strategi marketing baik offline maupun online. 2) Pembeli mendatangi kantor PT MIB. 3) Pembeli diberi pertanyaan terkait pekerjaan, dan pendapatannya berapa untuk memastikan layak atau tidaknya pembeli diberikan kredit. 4) Apabila pembeli sepakat membeli rumah, pembeli diminta mengisi formulir terkait akad, hak kewajiban dan sengketanya. Mawardi \& Susanti (2019) menunjukkan prosedur yang sama untuk mekanisme jual beli kredit di dealer Wafa Motor.

Akad yang dipakai oleh PT MIB yaitu akad Bit-ain Wattaqisth atau akad jual beli dengan pembayaran tempo apabila rumah sudah jadi. Apabila rumah belum jadi, menggunakan akad jual beli tanah, kemudian akad jasa bangun, dan terakhir akad supply bahan bangunan.

"Apabila rumah sudah jadi maka, akad yang dipakai dalam jual beli kredit rumah disini yaitu akad Bit ain wattaqsith atau akad jual beli bertempo yang mana sudah diperbolehkan dalam islam." 
Harga yang ditetapkan untuk penjualan tunai berbeda dengan sistem pembayaran secara kredit. Ketika dilakukan konfirmasi kepada pihak PT MIB, perusahaan merasa perhitungan tersebut tidak menyalahi ketentuan syariah, karena penambahan harga dilakukan sebagai kompensasi atas penundaan waktu pembayaran. Ketika menilik beberapa penelitian terdahulu disebutkan bahwa jual beli kredit diperbolehkan akan tetapi harus jelas takarannya, kuantitasnya dan waktunya (Nurhadi, 2017). Metode kredit mewajibkan seorang pembeli untuk bertanggungjawab sepenuhnya terhadap kewajibannya setelah akad dilaksanakan (Ilham, 2020).

Hasil observasi menunjukkan bahwa praktik jual beli kredit pada PT MIB telah memenuhi rukun jual beli yaitu penjual dan pembeli, kemudian ijab qabul, barang yang dipejualbelikan yaitu rumah, dan nilai tukar pengganti barang yaitu uang. Peneliti melihat adanya saling rela, saling ridho dan tidak adanya unsur keterpaksaan antar kedua belah pihak dalam bertransaksi. Namun demikian, peneliti tidak boleh mendokumentasikan dokumen akad Bit ain wattaqsith yang dilakukan oleh Pimpinan PT MIB dan Pembeli. Peneliti hanya diperbolehkan melihat isi akad dimana isinya adalah identitias pihak pertama dan kedua selaku penjual dan pembeli, harga kesepakatan pembelian rumah, sistem pembayaran, spesifikasi rumah, pengambilan keputusan apabila terjadi ketidaksesuaian perjanjian, penutup, kemudian tanda tangan.

PT MIB menyediakan berbagai opsi dalam akad dalam jual beli kredit yang dilakukannya. Salah satunya adalah kebijakan mengenai uang muka, pembeli dapat menentukan jenis pembeliannya dengan menggunakan uang muka ataupun tanpa uang muka. Perusahaan menetapkan adanya perbedaan harga antara harga tunai dengan harga kredit. Perbedaan harga tersebut diklarifikasi pemilik sebagai ganti atas tertundanya pembayaran yang dilakukan oleh pembeli dan sebagai antisipasi kerugian apabila terdapat perubahan harga tanah, harga bahan bangunan, upah tenaga kerja, dan biaya-biaya lainnya. Adapun proporsi pembiayaan dari penjualan kredit terdiri dari 60\% tanah, 10\% bahan bangunan, 10\% upah tenaga kerja dan $20 \%$ Biaya lain seperti pajak retribusi. Hasil wawancara lanjutan, pemilik memaparkan bahwa untuk kompensasi penundaan pembayaran secara kredit PT MIB menentukan kenaikan 10\% per tahunnya. Namun demikian angka $10 \%$ ini diperoleh darimana tidak dijelaskan secara detail. Untuk itu peneliti melakakukan observasi lanjutan guna mengklarifikasi akad jual beli yang dilakukan.

Berdasarkan hasil obsevasi lanjutan dalam proses akad jual beli kredit KPR, pihak PT MIB tidak memberitahukan secara detail kepada pembeli mengenai harga barang yang diperjualbelikan (KPR) dan berapa margin yang diambil karena adanya penundaan pembayaran pelanggan. Berdasarkan pemahaman peneliti dalam transaksi tersebut terdapat unsur gharar atau ketidakpastian yang dapat merugikan salah satu pihak. Akad dinyatakan sah apabila objek, harga dan waktunya diketahui secara jelas oleh kedua belah pihak yang bertransaksi. Apabila salah satu diantaranya samar-samar atau tidak jelas, maka hukum akad tersebut dilarang (Nurhadi, 2020). Hal ini juga kurang sesuai dengan definisi konseptual murabahah dalam SAK syariah dimana Murabahah adalah akad jual beli barang dengan harga jual sebesar biaya perolehan ditambah keuntungan yang disepakati dan penjual harus mengungkapkan biaya perolehan barang tersebut kepada pembeli (PSAK 102).

Hasil wawancara lanjutan ditemukan bahwa PT MIB menggunakan metode inflasi dan ekonomi alternatif dalam menentukan perbedaan penjualan rumah secara tunai dengan penjualan rumah secara kredit. Jika pembeli mengingingkan sistem angsuran selama 1 tahun, maka PT MIB akan menaikan harga 10\% dari harga tunai, jika mengambil 2 tahun maka besarnya kenaikan adalah $2 \times 10 \%=20 \%$ dan seterusnya. Skema perhitungan ini dibuktikan dengan penetapan harga yang tercantum pada brosur penjualan (Gambar 2) dan diperjelas dengan analisis perhitungan oleh peneliti (Gambar 1). 


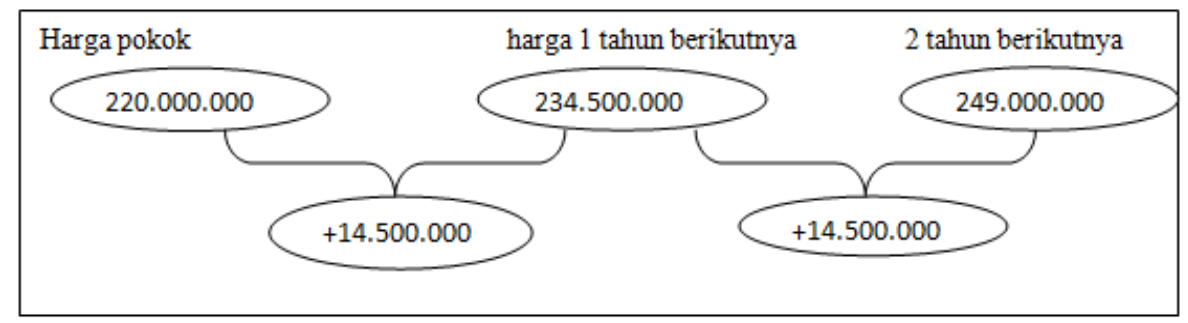

Gambar 1. Ilustrasi perhitungan skema kredit di PT MIB

\begin{tabular}{|c|c|c|c|c|c|c|c|c|c|c|c|}
\hline \multirow{4}{*}{ TIPE/LUAS RUMAH } & \multirow{4}{*}{ LB/LT (M2) } & \multirow{4}{*}{ HARGA TUNAI (Rp } & \multicolumn{9}{|c|}{ HARGA ANGSURAN } \\
\hline & & & \multirow{3}{*}{ UANG MUKARRp } & \multicolumn{2}{|c|}{ 3Tahun } & \multicolumn{2}{|c|}{5 Tahun } & \multicolumn{2}{|c|}{7 Tahun } & \multicolumn{2}{|c|}{10 Tahun } \\
\hline & & & & Harga (Rp) & Angsurara/Bulan & Harga & Angsuran/Bulan & Harga & Angsurara/Bulan & Harga & Angsuran/Bulan \\
\hline & & & & & $(\mathbb{R p})$ & (Rp) & (Rp) & (Rpp) & $\left(R_{p}\right)$ & $(\mathbb{R p})$ & (Rp) \\
\hline CAKRA & $40 / 72$ & 220.000 .000 & 75.000 .000 & 263.500 .000 & 5.236 .000 & 292.500 .000 & 3.625 .000 & 321.500 .000 & 2.935 .000 & 365.000 .000 & 2.417 .000 \\
\hline BASWARA & $46 / 80$ & 315.000 .000 & 110.000 .000 & 376.500 .000 & 7.042 .000 & 417.500 .000 & 5.125 .000 & 458.500 .000 & 4.149 .000 & 520.000 .000 & 3.417 .000 \\
\hline WUAYA & $60 / 80$ & 350.000.000 & 120.000 .000 & 419.000 .000 & 8.305 .000 & 465.500 .000 & 5.750 .000 & 511.000 .000 & 4.655.000 & 580.000 .000 & 3.833 .000 \\
\hline KUSUMA & $70 / 120$ & 485.000 .000 & 200.000 .000 & 570.500 .000 & 10.292.000 & 627.500 .000 & 7.125 .000 & 684.000 .000 & 5.768 .000 & 770.000 .000 & 4.750 .000 \\
\hline KUSUMA NEGARA & $70 / 120$ & 610.000 .000 & 200.000 .000 & 733.000 .000 & 14.805 .000 & 815.000 .000 & 13.250 .000 & 897.000 .000 & 8.298 .000 & 1.020 .000 .000 & 6.833 .000 \\
\hline
\end{tabular}

Gambar 2. Brosur Penjualan KPR di PT MIB

Metode inflasi diperbolehkan dalam syariah karena objek atau bentuk pertukarannya adalah barang dan nilai ekonomis barang tersebut setiap tahun pasti mengalami peningkatan. Cara menghitung presentase dengan metode inflasi, misalnya harga bahan material yaitu pasir pada tahun 2020 Rp 600.000/dam truk. Namun, setahun kemudian mencapai harga Rp 750.000. Maka besarnya inflasi:

$$
\begin{aligned}
& =\{(750.000-600.000) / 600.000)\} \times 100 \% \\
& =0,25 \times 100 \% \\
& =25 \%
\end{aligned}
$$

Jika dianalisis lebih lanjut, dapat diketahui bahwa 10\% yang ditetapkan oleh PT. MIB cukup signifikan karena berdasrkan opsi kredit yang ditawarkan jangka waktunya adalah 3 tahun, 5 tahun, 7 tahun dan 10 tahun. Jika seorang pembeli memutuskan untuk kredit selama 10 tahun maka besarnya kenaikan dari harga tunainya adalah $10 \times 10 \%=100 \%$. Berdasarkan SAK 102 (IAI, 2018) mengenai murabahah, dijelaskan bahwa pendapatan murabahah yang mengandung unsur pembiayaan signifikan dimasna penjual tidak menanggung risiko signifikan terkait kepemilikan persediaan harus mengikuti ketentuan dalam ISAK 101.

Dalam sistem jual beli kredit KPR pada PT. MIB sertifikat hak kepemilikan tanah hanya akan diberikan ketika pembeli sudah melunasi pembayaran dari seluruh angsuran. Hal ini berarti risiko yang ditanggung oleh penjual tidak signifikan. Untuk itu dasar analisis selanjutnya menggunakan ISAK 101. Asumsi perhitungan yang digunakan dalam analisis adalah KPR dengan tipe Cakra (disajikan dalam Gambar 3 dan Tabel 1).

Harga pembelian barang
Uang muka
Total pembiayaan
Margin
Jangka waktu cicilan
Cicilan per tahun

$$
\begin{gathered}
\text { Rp 220.000.000 } \\
\text { Rp 75.000.000 } \\
\text { Rp } 145.000 .000 \\
10 \% \\
10 \text { tahun } \\
\text { Rp } 14.500 .000
\end{gathered}
$$

Gambar 3. Ilustrasi perhitungan harga jual KPR jenis Cakra

Jati :JurnalAkuntansiTerapan Indonesia, 2020 75 
Namun demikian ketika dicermati kembali ISAK 101 (IAI, 2018), yang dimaksudkan dengan risiko signifikan yang kemungkinan dihadapi penjual dalam murabahah tanggung dengan penjualan signifikan adalah: 1) risiko perubahan harga persediaan, 2) kusangan dan kerusakan persediaan, 3) biaya pemeliharaan dan penyimpanan persediaan, serta 4) risiko pembatalan pesanan sepihak. Risiko - risiko tersebut berkaitan erat dengan kegiatan operasional developer KPR dimana harga tanah dan bahan bangunan mengalami peningkatan yang cukup signifikan dari tahun ke tahun. Ketika bangunan sudah selesai proses konstruksi dan pembeli membatalkan secara sepihak, developer akan menghadapi risiko kerusakan dan keusangan serta biaya pemeliharaan yang cukup tinggi. Dengan demikian, analisis selanjutnya dilakukan dengen menggunakan dasar ekonomi alternatif.

Tabel 1. Angsuran pendapatan PT MIB Sesuai PSAK 102 dan ISAK 101.

\begin{tabular}{cccc}
\hline Tahun & Harga pokok+angsuran & Marjin (Rp) & Margin (\%) \\
\hline 1 & Rp. 234.500 .000 & Rp. 14.500 .000 & $10 \%$ \\
2 & Rp. 249.500 .000 & Rp. 14.500 .000 & $10 \%$ \\
3 & Rp. 263.500 .000 & Rp. 14.500 .000 & $10 \%$ \\
4 & Rp. 278.000 .000 & Rp. 14.500 .000 & $10 \%$ \\
5 & Rp. 292.500 .000 & Rp. 14.500 .000 & $10 \%$ \\
6 & Rp. 307.000 .000 & Rp. 14.500 .000 & $10 \%$ \\
7 & Rp. 321.500 .000 & Rp. 14.500 .000 & $10 \%$ \\
8 & Rp. 336.000 .000 & Rp. 14.500 .000 & $10 \%$ \\
9 & Rp. 350.500 .000 & Rp. 14.500 .000 & $10 \%$ \\
10 & Rp. 365.000 .000 & Rp. 145.500 .000 & $100 \%$ \\
\hline
\end{tabular}

Pada saat wawancara peneliti tidak diberitahukan secara jelas darimana presentase $10 \%$ (sepuluh persen) tersebut sehingga peneliti melakukan analisis yang disesuaikan dengan suku bunga bank indonesia dan bunga deposito. Besarnya suku bunga bank indonesia adalah $6 \%$, sedangkan suku bunga deposito adalah 12,5\%. Apabila pihak PT MIB menggunakan 10\% sebagai margin per tahun, diasumsikan perusahaan mengambil nilai tengah dari presentase suku bunga bank indonesia dan suku bunga deposito (Gambar 4). Hal ini didasarkan pada wawancara pada sesi sebelumnya kepada pemilik yang menyatakan bahwa PT. MIB menggunakan metode inflasi dan ekonomi alternatif untuk menentukan presentase kenaikan harga yang disesuaikan dengan jangka waktu pengangguhan pembayaran (kredit).

Suku bunga BI

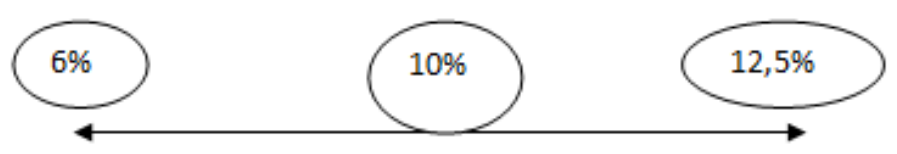

Gambar 4. Posisi presentase marjin PT MIB

Konsep metode ekonomi alternatif (economic value of time) sedikit berbeda dengan konsep time value of money. Konsep time value of money didasarkan pada dua asumsi dimana harga barang dan jasa akan naik seiring kondisi inflasi dan adanya preferensi dari manusia untuk menggunakan uang dalam kegiatan konsumsi saat ini daripada di masa yang akan datang (Harjoni, 2019; Maghfiroh, 2019; Pertiwi, 2019). Dengan demikian nilai uang akan mengalami penurunan seiring berlalunya waktu. Untuk itu ketika terjadi penangguhan pembayaran diperlukan kompensasi dalam presentase tertentu. Perlakuan uang dalam hal ini akan bertumbuh seperti sel hidup yang akan terus bertumbuh sesuai dengan 
bertambahnya jangka waktu. Dalam konsep bisnis konvensional dikenal istilah bunga dengan sistem anuitas.

Konsep economic value of time memperlakukan uang hanya sebagai sarana pembayaran yang dimiliki public. Agar barang dan jasa dapat berputar sehingga menghasilkan kesejahteraan bagi sesama, membutuhkan perputaran uang yang semakin cepat (Harjoni, 2019; Maghfiroh, 2019; Pertiwi, 2019). Untuk itu ketika terjadi penangguhan pembayaran, diperbolehkan mengambil kompensasi atas jangka waktu penundaan tersebut. Dasar perhitungan dari penundaanpun dilakuakn harus dengan pertukaran barang dan jasa secara riil. Dalam konsep ini margin 10\% setiap tahun langsung dikalikan dengan poko secara tetap karena dasar perhitungannya adalah harga barang.

(Harga Tunai - Uang Muka) x Jumlah Prasentase per tahun,

(Harga tunai pada waktu 3 tahun - Uang Muka): Kurun waktu,
Persamaan 1

Persamaan 2

Persamaan 1 dan Persamaan 2 merupakan rumus yang digunakan oleh PT. MIB untuk menentukan besarnya harga kredit dan jumlah angsuran per bulan. Penghitungan ulang skema kredit KPR type Cakra adalah sebagai berikut; Margin setiap tahun 10\% dengan harga tunai Rp. 220.000.000 dikurangi DP Rp. 75.000 .000 maka hasilnya Rp. 145.000.000, akan dikembalikan sebesar Rp. 220.000 .000 dengan margin Rp. 14.500 .000 dari presentase $10 \%$. Jadi, dengan margin 10\% tersebut dapat diketahui bahwa Rp. 220.000.000 benar-benar ekivalen dengan Rp. 234.500.000. Metode ini tersebut diperbolehkan secara syariah karena dasar pengenaan marjin berada pada kegiatan ekonomi penjualan rumahnya.

Berdasarkan analisis atas faktor-faktor risiko signifikan dan jangka waktu KPR yang cukup panjang, PT MIB menerapkan sejumlah kebijakan. Adapun kebijakan perusahaan untuk meminimalkan resiko gagal bayar dilakukan beberapa cara diantaranya; 1) Pembaruan akad 2) Meminta pemilik rumah untuk menjual dengan waktu 2-3 bulan ( pihak PT MIB bersedia untuk dimintai pertolongan apabila dalam kurun waktu tersebut belum terjual), 3) Pihak PT MIB bersedia membeli rumah didasarkan atas saling ridho antar kedua belah pihak4) Pihak PT MIB hanya mengambil kekurangan pembayarannya saja.

PT MIB juga memberikan Jaminan dan Garansi Perawatan Rumah selama periode penyelesaian jual beli kredit. PT MIB akan memberikan sertifikat rumah apabila pembeli sudah membayar secara lunas. Bukti pelunasan pembayaran akan dibawa ke Notaris untuk penerbitan akte jual beli (AJB) dengan jangka waktu penyelesaian maksimal 3 bulan. Akte jual beli diterbitkan dan sertifikat baru bisa dibaliknamakan. PT MIB memberikan waktu 1 sampai 2 tahun untuk garansi perawatan rumah tergantung mutu dan kualitas bangunan maupun harga jual.

Keuntungan membeli rumah di developer syariah dibandingkan KPR konvensional antara lain, diridhoi oleh Allah SWT, menurut pembeli pelayanannya lebih mudah, harga lebih murah dibanding KPR konvensional, pembeli merasa tenang karena terhindar dari transaksi haram, transaksinya jelas, jelas perhitungannya karena sudah tercantum di brosur penjualan, dan lebih berkah. Hal ini didukung oleh pernyataan hasil penelitian terdahulu (Firmansyah \& Indika, 2017) mayoritas responden memilih KPR Syariah tanpa bank dibanding KPR di Bank syariah dalam membeli rumah. Mereka beranggapan masih adanya praktik riba di KPR bank syariah. Mereka lebih memilih KPR Syariah tanpa bank karena dianggap solusi terbaik untuk terhindar dari praktik riba.

\section{KESIMPULAN}

Akad yang digunakan oleh PT MIB adalah akad Bit-ain Wattaqsith atau jual beli kredit. Pada saat akad terjadi peneliti melihat pihak PT MIB tidak memberitahu pembeli terkait 
margin 10\% setiap tahun sehingga, dalam transaksi tersebut terdapat unsur gharar atau ketidakpastian yang dapat merugikan salah satu pihak. Skema perhitungan harga jual beli kredit pada PT MIB menggunakan metode inflasi dan ekonomi alternatif. Tinjauan lebi spesifik sesuai Al Qur'an, Hadis, Ijma dan PSAK 102, ISAk 101 menunjukkan bahwa praktik tersebut merupakan konsep economic value of money yang diperbolehkan dalam islam.

Keterbatasan peneliti terkait dengan waktu penelitian dan analisis data yang dikaji belum mampu menggambarkan analisis yang mendalam terkait prinsip syariah dikarenakan ketersediaan informasi yang terbatas. Oleh karena itu, untuk peneliti selanjutnya harus mengkaji skema penerapan akuntansi syariah lebih mendalam berdasarkan sumber Al-qur'an dan Hadist, serta sumber yang relavan lain dikaitkan dengan kondisi objek yang diteliti, utamanya pembahasan mengenai perbedaan harga secara lebih spesifik jika menggunakan time value of money dibandingkan penggunaan konsep economic time of value.

\section{DAFTAR PUSTAKA}

Al-Banjari, F. (2016). Panduan Penulisan Akad Bisnis Syariah. Penerbit Klinik Binsis Syariah.

Apriyanti, H. W. (2017). Akuntansi Syariah: Sebuah Tinjauan Antara Teori Dan Praktik. Jurnal Akuntansi Indonesia, 6(2), 131. https://doi.org/10.30659/jai.6.2.131-140

Firmansyah, E. A., \& Indika, D. R. (2017). Kredit Pemilikan Rumah Syariah Tanpa Bank: Studi di Jawa Barat. Jurnal Manajemen Teori Dan Terapan | Journal of Theory and Applied Management, 10(3), 223.

Harjoni. (2019). Penerapan Konsep Time Value of Money dan Kritik Pelaksanaan. Jurnal J-Iscan, $1(1), 67-82$.

IAI. (2018). SAK : Standar Akuntansi Keuangan. Ikatan Akuntan Indonesia. Jakarta

Ilham, A. A. F. (2020). Kajian Penelitian Tentang Hukum Jual Beli Kredit. Jurnal Suhuf, 32, 50-58.

Irawan, F. (2019). Determinan Konsumen Dalam Pembelian Rumah (KPR) Developer Syariah. Jurnal Ilmu Pendidikan Dan Ekonomi, 4, 6-8. https://doi.org/10.16309/j.cnki.issn.10071776.2003.03.004

Khaer, M., \& Nurhayati, R. (2019). Jual Beli Taqsith (kredit) dalam Perspektif Hukum Ekonomi Islam. Jurnal Al-Maqasidhi, 2(1), 99-110.

Maghfiroh, R. U. (2019). Konsep Nilai Waktu dari Uang dalam Sudut Pandang Ekonomi Islam. El-Qist: Journal of Islamic Economics and Business (JIEB), 9(2), 186-195. https://doi.org/10.15642/elqist.2019.9.2.186-195

Maulidi AC, A. (2014). Akuntansi Syariah; Pendekatan Normatif, Historis dan Aplikatif. Iqtishadia: Jurnal Ekonomi \& Perbankan Syariah, 1(1), 59.

Mawardi, S., \& Susanti, N. I. (2019). Analisis Jual Beli Kredit Sepeda Motor Dengan Sistem Hiwalah ( Studi Kasus Masyarakat Desa Tegalsari Kecamatan Tegalsari Kabupaten Banyuwangi Yang Mengajukan Kredit Di Dealer Wafa Motor Dan Melalui Leasing Fif ( Financial Information Finance ). $5(2), 127-144$.

Nasution, A. M. (2016). Jual Beli Kredit Ditinjau Dari Persfektif Hukum Islam. Jurnal Yurisprudentia, 2(2), 19-34.

Nurhadi. (2017). Hilah Syariah Kredit Bank Konvensional ( Maqashid Jual Beli Kredit ( Lain Kontrak Lain Akad )). Jurnal Hukum Islam, XVII(2), 109-131.

Nurhadi. (2020). Halal Haram akad Murabahah Bil Wakalah Pembiayaan Perbankan Syariah. Yurisprudentia: Jurnal Hukum Ekonomi, 6(1), 75-96.

Pertiwi, D. (2019). Uang Dan Konsep Time Value of Money Dalam Pandangan Islam. ESA: Jurnal Ekonomi Syariah, 2(1), 90-105.

Qarizah, A., \& Prabowo, S. P. (2013). Pengaruh Bauran Pemasaran Terhadap Keputusan Nasabah Mengambil KPR Syariah Bank Jatim Syariah Surabaya. Jurnal Ekonomi Islam, 53(9), 16891699. https://doi.org/10.1017/CBO9781107415324.004

Rahmanti, V. N. (2012). Sebuah Kajian Akuntansi Syariah Masih Sulit Tumbuh Subur di 
Indonesia. Jurnal Akuntansi $\mathcal{E}$ Investasi Vol. 13 No. 2, Halaman : 161-179, Juli 2012, 13(2), 161 179.

Wardi, J., \& Putri, G. E. (2011). Analisis Perlakuan Akuntansi Syariah Untuk Pembiayaan Murabahah, Mudharabah, Serta Kesesuaiannya dengan PSAK No. 102, dan PSAK No. 105. Jurnal Pekbis, Vol. 03, N(Maret), 447-455. 